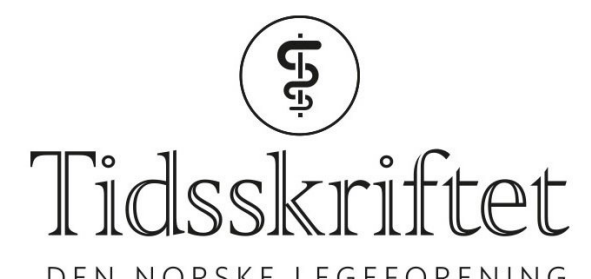

DEN NORSKE LEGEFORENING

\title{
Kirurgen som lærer og underviser
}

ANMELDELSER

KJETIL SøREIDE

Gjesteprofessor, Universitetet i Edinburgh

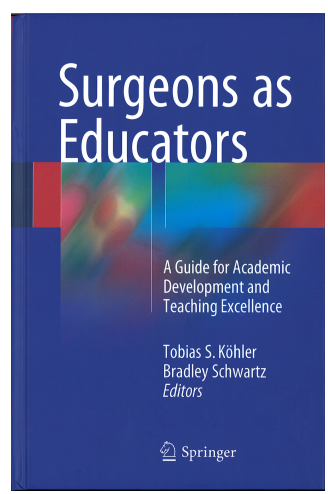

Tobias S. Köhler

Bradley Schwartz, red.

Surgeons as educators

A guide for academic development and teaching excellence. $530 \mathrm{~s}$, tab, ill. Cham: Springer, 2018. Pris EUR 170

ISBN 978-3-319-64727-2

Denne boken har som formål å hjelpe leseren å forstå moderne prinsipper innen kirurgisk undervisning og ervervelse av ferdigheter innen kirurgiske fag. Målgruppen er kirurger på alle nivåer, men særlig de som er ansvarlige for overordnet struktur av utdanningsprogrammer for kirurgiske subspesialiteter. Boken er redigert av to renommerte urologer fra Nord-Amerika, der også alle forfatterne er fra.

Boken er solid ombundet, med tabeller og fine figurer. Noen kapitler er ganske teksttunge og kunne vært brukket opp med noen pedagogiske grep. Innholdet er imidlertid spennende og aktuelt, med gjennomgang av moderne konsepter og aktuelle eksempler. Ikke minst opplyses det om dannelse av kirurger, noe som i for stor grad har vært fraværende i hverdag og kurssammenheng. Kapitlene inneholder et moderat antall referanser til kjernelitteratur. Innholdet oppleves som relevant for kirurger, da mange av eksemplene er hentet fra nettopp kirurgisk hverdag og erfaringer fra kirurgistudier. At flere av prinsippene og eksemplene er fra fagområdet urologi, tilskrives redaktørenes bakgrunn, men de oppleves som generelt gyldige for kirurgisk utdanning.

Boken har 26 kapitler inndelt i tre seksjoner. Første del tar for seg basisprinsipper og 
grunnmodeller for undervisning og læring. Kapitlene går fra det historiske «see one, do one, teach one» til moderne mål for pensumlister, måling av ferdigheter i minimalinvasiv kirurgi, hvordan lære leger å undervise og hvordan undervisning og læring foregår (eller burde foregå) på operasjonsstuen. Midtseksjonen dekker konsepter og hensyn i

fragmenterte arbeidsplaner, men beskriver også hvordan utdanning er med på å forbedre kvaliteten på helsetjenesten. Moderne teorier for bruk av simulering og utvikling av ferdighetssenter samt konsepter som «coaching», «mentoring» og utvikling av «professionalism» omtales. Siste del omhandler en rekke viktige temaer som strekker seg fra det praktiske til det mer metafysiske. Her omtales kirurgens reaksjon når feil oppstår; pasientsikkerhet; undervisning i ledelse og i etikk; kirurgisk ergonomi; regnskap, fakturering og koding; utbrenthet og jobb-fritid-balanse.

Dette er en veldig nyttig bok som, bortsett fra en del eksempler typisk for medisinsk praksis i Nord-Amerika, har bred og aktuell relevans for utdanning og dannelse av kirurger. Boken inneholder konsepter som burde trekkes mye tydeligere inn i dagens undervisning av medisinstudenter, leger i spesialisering i kirurgi og spesialister. Innholdet er tidsaktuelt for alle som praktiserer kirurgi, og ikke bare dem som lager utdanningsprogrammene. Den bør derfor leses av alle som bevisst eller ubevisst underviser yngre eller eldre kolleger i den kirurgiske hverdagen.

Publisert: 21. august 2018. Tidsskr Nor Legeforen. DOI: 10.4045/tidsskr.18.0285

(C) Tidsskrift for Den norske legeforening 2020. Lastet ned fra tidsskriftet.no 